\title{
EFFECTS OF WAVE BREAKING AND BEACH SLOPE ON TOE SCOUR IN FRONT OF A VERTICAL SEAWALL
}

\author{
Qingping Zou ${ }^{1}$, Zhong Peng ${ }^{2}$ and Pengzhi Lin $^{3}$
}

\begin{abstract}
Scour in front of coastal structures is a major threat to structural stability and safety of properties behind. In this study, a Reynolds Averaged Navier-Stokes Solver (RANS) is combined with a Volume of Fluid (VOF) (RANS-VOF) surface capturing scheme to investigate the wave interactions with a Seawall and its adjacent sea bed. The main objective is to investigate the effects of wave breaking and beach slope on toe scour in front of a vertical wall.
\end{abstract}

Keywords: Vertical Seawall, beach lowing, toe scour, standing wave, breaking wave, RANS

\section{INTRODUCTION}

Scour in front of coastal structures is a vital threat to structural stability and safety of properties behind. Wave breaking is believed to be a significant factor in sediment transport and beach profiles changes. The experimental study by Fredsøe and Sumer (1997) indicates that the steady streaming generates a scour hole in front of a breakwater while the plunging breaker generates a scour hole at the lee-side of the breakwater. Tsai et al. (2009) studied the toe scour of seawalls on a beach slope of 1:5 under regular waves in the lab. They concluded that the scour depth induced by a plunging breaker is larger than that by a spilling breaker or a non-breaking wave.

In case of non-breaking waves, Sumer and Fredsoe, (2002) and Sumer (2007) found that the reflection from the breakwater forms a standing wave which generates the steady streaming in front of breakwater, consisting of bottom and top recirculating cells. The formation of bottom cell is related to the boundary layer over the bed and the sediment motion on the bed responds to these recirculating cells. Consequently a scour /deposition pattern in front of the breakwater emerges in the form of alternating scour and deposition areas lying parallel to the structure. However, in case of breaking waves, Sumer (2007) mentioned that the complex process of wave breaking generates a strong downward flow in the form of a jet to erode the bed and mobilize the sediment at the toe of vertical wall, which presumably leads to scour at the toe of a seawall.

Gislason et al. (2009) investigated the two-dimensional scour and deposition in front of vertical and sloping Seawalls using a 3-D Navier-Stokes solver, coupled with a k- $\omega$ turbulence model and a morphologic model. They reproduced the well known alternating scour/deposition pattern in front of the breakwater (e.g., Sumer and Fredsoe, 2002). However, effect of wave breaking is not considered in their work. In their Study, the free surface is tracked by integrating in time the kinematic boundary conditions based on the free surface volume flux.

In this study, a Reynolds Averaged Navier-Stokes Solver (RANS) combined with a Volume of Fluid (VOF) surface capturing scheme is used to simulate the hydrodynamics of wave interactions with a seawall. This model is further coupled with a bed-load sediment transport equation and morphological model in order to predict beach profile changes in front of the seawall. The main objective is to investigate the effects of wave breaking and beach slope on toe scour in front of a vertical wall.

\section{EXPERIMENTS}

Medium scale physical model tests of scour in front of seawalls were performed in the wave flumes (45 $\mathrm{m}(\mathrm{L}) \times 1.2 \mathrm{~m}(\mathrm{~W}) \times 1.7 \mathrm{~m}(\mathrm{H}))$ at HR Wallingford in the UK (HR Wallingford, 2006, Sutherland et al 2006)). Waves were generated using a piston-type wave maker with maximum stroke of $\pm 0.6 \mathrm{~m}$ and maximum operating depth of $1.4 \mathrm{~m}$. Test setup had a $19.2 \mathrm{~m}$ long 1:30 smooth concrete slope from the flume floor up to an elevation of $0.64 \mathrm{~m}$. Test section was a $5.14 \mathrm{~m}$ long sand bed filled with Redhill 110 sand. Mean sand diameter, d50=0.111mm, kinematic viscosity $\mathrm{v}=1 \times 10^{-6} \mathrm{~m}^{2} / \mathrm{s}$ and sediment density $_{\mathrm{s}}=2650 \mathrm{~kg} / \mathrm{m}^{3}$. More details about the experiment can be found in Sutherland et al. (2006). In

\footnotetext{
${ }^{1}$ Dept. of Civil and Environmental Engineering, University of Maine, Orono, ME 04469, USA qingping.zou@maine.edu

2 Harbor, Coastal and Offshore Engineering, Deltares, Delft, 2629HD, Netherlands

${ }^{3}$ State Key Laboratory of Hydraulics and Mountain River Engineering, Sichuan University, 610065, Chengdu, China
} 
this study, these experiments will be used to validate the model simulation of toe scour in front of a vertical Seawall on a sloping beach.

\section{NUMERICAL MODEL}

\section{Hydrodynamic model}

The Reynolds Averaged Navier-Stokes-Volume of Fluid (RANS-VOF) model, developed by Lin and Liu (1998), solves the Reynolds-Averaged Navier-Stokes equation for the mean flow field and the nonlinear $\mathrm{k}-\varepsilon$ equations for the turbulent kinetic energy, $\mathrm{k}$, and the turbulence dissipation rate, $\varepsilon$. The Volume of Fluid method is employed to capture free surface. During the computation, a no-slip boundary condition at the solid boundaries and a zero-stress condition at the free surface are employed. Turbulent kinetic energy, $\mathrm{k}$, and dissipation rate, $\varepsilon$, are assumed to be a function of distance from the solid surface and have zero gradient at the free surface. An active wave generating-absorbing wavemaker located at the inlet is applied to generate waves and simultaneously absorb the reflected waves from the structures (Troch and De Rouck, 1999). More detailed information about the model can be found in Lin \& Liu (1998) and Peng and Zou (2011). Recently this model has been further developed and used widely to investigate wave-structure interactions and subsequent coastal flood risk (Garcia et al. 2004; Lara et al. 2006; Zou \& Peng 2011; Zou et al 2012)

The cell size in the y-direction varies from $0.01 \mathrm{~m}$ in the near bed region to $0.02 \mathrm{~m}$ away from the bed. The cell size in the $\mathrm{x}$-direction is $0.05 \mathrm{~m}$. Numerical model setup is illustrated in Figure 1. RANS-VOF model has been extended to deal with complex bathymetry, such as a ripple bed in this study. In the original code, the bathymetry is defined by a series of conic sections whose equations are provided by the user. This treatment is too tedious for large and complicated bathymetry. In the updated code, complicated bathymetry can be read directly from an input file.

\section{Sediment transport model}

Due to the complexity and uncertainty of sediment transport, empirical formulae based on experiments have been implemented to describe this process in previous studies (e.g., Pedrozo-Acuña et al., 2006; Bakhtyar et al., 2009). Madsen (1991) introduced a formula based on the work by Meyer-Peter and Muller (1948), which accounts for slope corrections and the angle of repose.

$$
\frac{q(t)}{\sqrt{(s-1) g d_{50}^{3}}}=\frac{C}{1+\frac{\tan \beta}{\tan \phi}}\left(\theta-\theta_{c r}\right)^{3 / 2} \frac{u_{b}}{\left|u_{b}\right|}
$$

where $q(t)$ is instantaneous sediment transport rate; $s=\rho_{s} / \rho$ is the specific density, where $\rho_{s}$ is the grain density and $\rho$ is the water density; $d_{50}$ is the mean grain diameter, $g$ is the gravity; $C$ is sediment transport efficiency; $\beta$ is the beach slope and $\Phi$ is the angle of repose; $u_{b}$ is the instantaneous free stream velocity close to bed. $\theta=\frac{0.5 f u_{b}^{2}}{(s-1) g d_{50}}$ is the shields parameter, $\mathrm{f}$ is the bottom friction factor.

This formula has been widely used in the swash zone of sandy beaches (e.g., Butt and Russell, 2000; Larson et al., 2001) and therefore it will be employed in this study to obtain the sediment transport rate.

A threshold shear stress for sediments on a sloping bed at angle $\beta$ to the horizontal bed, is related to the direction of horizontal component of near-bed flow, for flow in the up- and down- slope direction respectively.

$$
\begin{aligned}
& \theta_{\beta c}=\theta_{c o} \cos \beta\left(1-\frac{\tan \beta}{\tan \phi}\right) \\
& \theta_{\beta c}=\theta_{c o} \cos \beta\left(1+\frac{\tan \beta}{\tan \phi}\right)
\end{aligned}
$$


where $\theta_{\beta c}$ is the critical value of $\theta$ for the initiation of sediment motion at the sloping bed and $\theta_{\text {co }}$ is the critical shields parameter for the initiation of sediment motion on a horizontal bed. $\theta_{\text {co }}$ is a function of the grain Reynolds number (Sumer and Freds\$e, 2002, p.10) and it is approximately 0.06 in this study.

The theoretical expression for the friction factor can be approximated by (Fredsoe and Deigaard, 1992)

$$
f= \begin{cases}0.04\left(\frac{a}{k_{N}}\right)^{-\frac{1}{4}}, & \frac{a}{k_{N}}>50 \\ 0.4\left(\frac{a}{k_{N}}\right)^{-\frac{3}{4}}, & \frac{a}{k_{N}}<50\end{cases}
$$

where $\mathrm{k}_{\mathrm{N}}$ is bed roughness length (around $1 / 12$ of grain size), and $\mathrm{a}=\mathrm{U}_{0} * \mathrm{~T} / 2 \pi$, bottom free stream velocity, $\mathrm{U}_{0}$ is taken as the maximum value of the measured velocity at $5 \mathrm{~cm}$ above the bed and $\mathrm{T}$ is incident wave period.

\section{Morphology model}

The bed profile is updated by solving the sediment conservation equation based on the time-averaged sediment transport rates from a bed-load sediment transport equation (1) (Fredsøe and Deigaard, 1992, chapter 11):

$$
\frac{\partial q(t)}{\partial x}=-(1-n) \frac{\partial z}{\partial t}
$$

where $\mathrm{z}$ is the bed level and $\mathrm{n}$ is the beach porosity, $\mathrm{n}=0.44$ is used in this study. The sand-slide model of Liang and Cheng, (2005) is modified and used to resolve the avalanching process and five-point Gaussian average is applied to the newly updated bed levels to smooth out the small-scale bed features.

\section{MODEL RESULTS}

The model is validated against the toe scour experiment for a regular wave on a flat bottom in front of a vertical wall, described in Gislason et al. (2009). The model prediction of bed profile are in a good agreement with the measurements after 300 waves. Model is then setup in the same way as the toe scour experiments of random waves over a sloping bed by Sutherland et al (2006) (cf. figure 1). The vertical wall is located at $\mathrm{x}=28 \mathrm{~m}$ in figure 1 . The model-data comparisons are used to study the toe scour over a sandy beach with a 1:30 slope in front of a vertical wall, with particular attention to the effects of wave breaking and water depth. Random waves are generated using the JONSWAP spectrum. Table 1 shows the key parameters for 3 examples model results out of numerous test runs conducted.

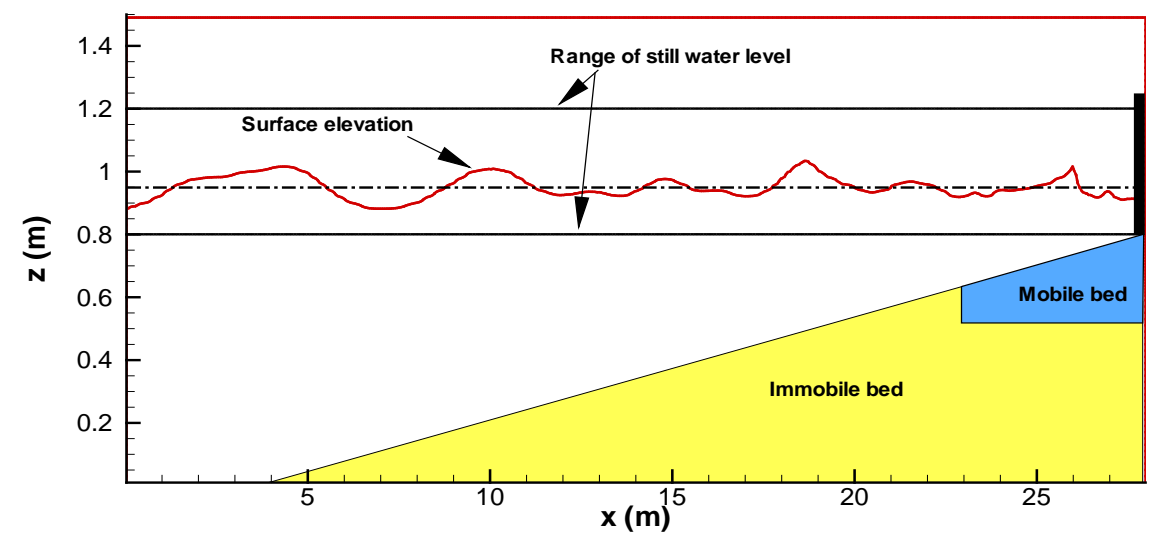

Figure 1 Numerical model setup and computation domain 


\begin{tabular}{|l|l|l|l|l|}
\hline \multicolumn{5}{|l|}{ Table 1. Examples test runs for toe scour on a sloping beach } \\
\hline Case No. & Hs & Tp & $h_{0}$ & $h_{\text {toe }}$ \\
\hline 1 & 0.2 & 3.24 & 0.95 & 0.1 \\
2 & 0.2 & 1.87 & 1.0 & 0.2 \\
3 & 0.2 & 1.87 & 1.25 & 0.4
\end{tabular}

\section{Case 1: low water level}

Random waves were generated from Jonswap spectrum with significant wave height $\mathrm{H}_{\mathrm{s}}=0.2 \mathrm{~m}$, peak wave period $T_{p}=3.24 \mathrm{~s}$, deep water depth $h_{0}=0.95 \mathrm{~m}$ and water depth at the toe of the wall $h_{\text {toe }}=0.1 \mathrm{~m}$. Figure 2 indicates that the predicted wave height is in a good agreement with the observation. As shown in figure 2, the wave height remains almost the same from $x=0$ to $x=23 \mathrm{~m}$ and decreases dramatically shoreward from $x=23 \mathrm{~m}$, indicating this location is the wave breaking point for most wave components . As the wave approaches the wall further, the wave height increases again at a location closer to the vertical wall $(x=28 \mathrm{~m})$. The reflected wave from the vertical wall leads to partial standing wave and thus larger wave height in this area.

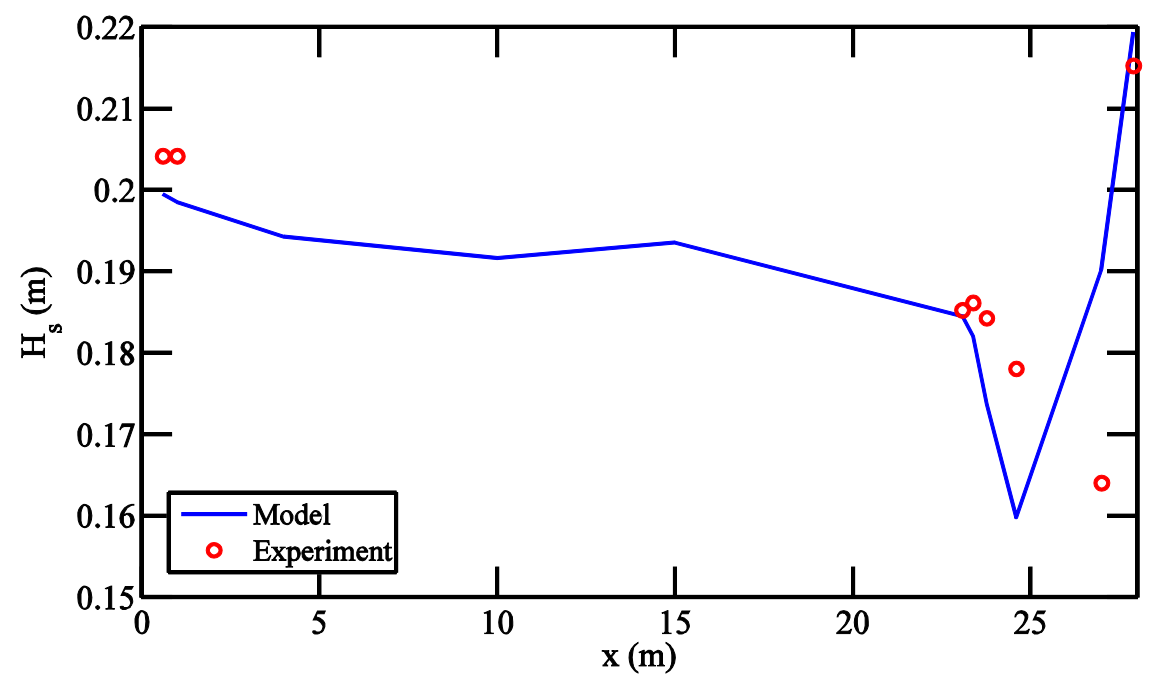

Figure 2 Model-data comparison of cross shore evolution of significant wave height.

The beach profile evolves from the initially smooth profile (black dotted line) to an undulating profile (blue dashed line) in figure 3. There is a large scour area close to the vertical wall followed by a small deposition area immediately seaward. Waves tend to break offshore so that wave energy is largely dissipated before reaching the Seawall. Scour is mainly induced by the near bottom offshore current generated by the breaking and the partial standing waves adjacent to the wall. The beach profile and scour and deposition pattern agrees reasonably well with measurements. The calculated maximum scour depth and deposition also compare well with the measurements. 


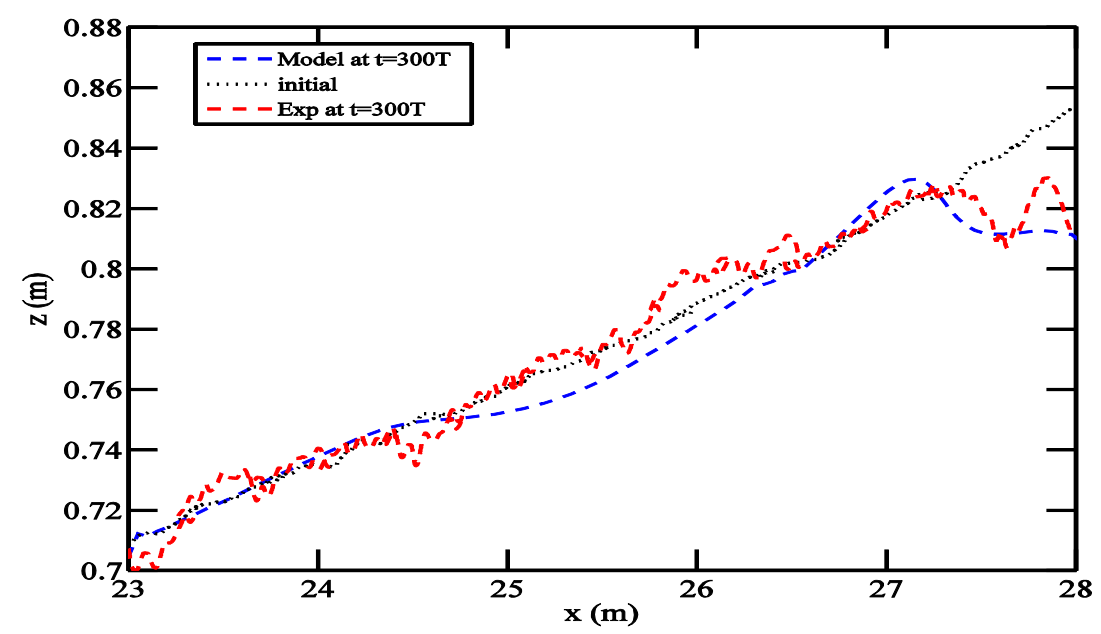

Figure 3 Comparison of model predicted scour and deposition with measurements for case $1 \mathrm{Hs}=0.2 \mathrm{~m}$, $\mathrm{Tp}=3.24 \mathrm{~s}$, htoe $=0.1 \mathrm{~m}$.

\section{Case 2: mid water level}

Random waves were generated from Jonswap spectrum with significant wave height $\mathrm{H}_{\mathrm{s}}=0.2 \mathrm{~m}$, peak wave period $\mathrm{T}_{\mathrm{p}}=1.87 \mathrm{~s}$, water depth at the toe of the wall $\mathrm{h}_{\mathrm{toe}}=0.2 \mathrm{~m}$. As can be seen from Figure 4 , the predicted beach profile as well as the calculated maximum scour depth and deposition agrees well with the measurement after 300 waves. The initial beach profile is taken from the measurements. Compared with Case 1 results in Figure 3, Figure 4 shows that the horizontal extent of the toe scour decreases for smaller incident wave period and slightly larger water depth in Case 2 . The offshore boundary of scour zone is at $x=27.4 \mathrm{~m}$ for $T_{p}=1.87 \mathrm{~s}$ in Case 2 and at $\mathrm{x}=27 \mathrm{~m}$ for $\mathrm{T}_{\mathrm{p}}=3.24 \mathrm{~s}$ in Case 1 . Both the model and experiment indicate a significant deposition just seaward of the scour area for Case 2 . These differences between Case 2 and Case 1 is mainly due to the change in the relative water depth at the toe of the vertical wall, i.e., the relative water depth, $h_{\text {toe }} / L_{\text {deep }}$, is 0.042 for $T_{p}=1.87 \mathrm{~s}$, Case 2 and 0.01 for $T_{p}=3.24$ $\mathrm{s}$, Case 1 . The intermediate water depth in this case allows bigger waves to arrive at the structure without breaking. The bigger waves in turn generate larger scour and deposition at the structure.

Given this wave condition, similar to the laboratory observations by Sutherland (2006), our model simulation shows that waves tend to break onto the structure and a partial standing wave is formed inside the surf zone. Our model results also indicate that water plunging upon the face of the seawall to the bed and produce strong vortex, streaming velocity and turbulence near the wall, resulting in the deepest scour depths and depositions.

\section{Case 3: high water level}

Random waves were generated from Jonswap spectrum with significant wave height $\mathrm{H}_{\mathrm{s}}=0.2 \mathrm{~m}$, peak wave period $\mathrm{T}_{\mathrm{p}}=1.87 \mathrm{~s}$, water depth at the toe of the wall $\mathrm{h}_{\mathrm{toe}}=0.4 \mathrm{~m}$. In contrast with Case 1 and 2 shown in figures 3 and 4 , the bed profile change is small and undulated with alternating scour and deposition pattern . This is mainly due to the larger water depth at the toe of the vertical wall in this test case. There is little wave breaking and the near bottom velocity is not large enough to move significant amount of sediment within the mobile bed area (Figure 1), and therefore there is small scour depth and deposition.

\section{CONCLUSIONS}

Present model can reproduce the observed scour and deposition processes in front of a seawall on a flat bottom and a sloping beach. In the presence of beach slope, the strength and spatial distribution of streaming velocity and bottom orbital velocity along the seabed are altered significantly by the wave randomness, wave breaking type and location, as well as the breaking induced wave reflection. The former largely determines the magnitude and direction of sediment transport. In particular, the breaking location and type are key factors in scour formation. At low water depth, wave breaks offshore, a partial standing wave and relatively small toe scour occurs at the wall. At intermediate water depth, the 
deepest scour depth is found in case of plunging breaker on the wall. At large water depth, very little breaking happens and near bottom velocity is not large enough to move significant amount of sediment within the mobile bed area so that scour and deposition are minimum. Model result also indicates that the extent of scour area increases with the wave period.

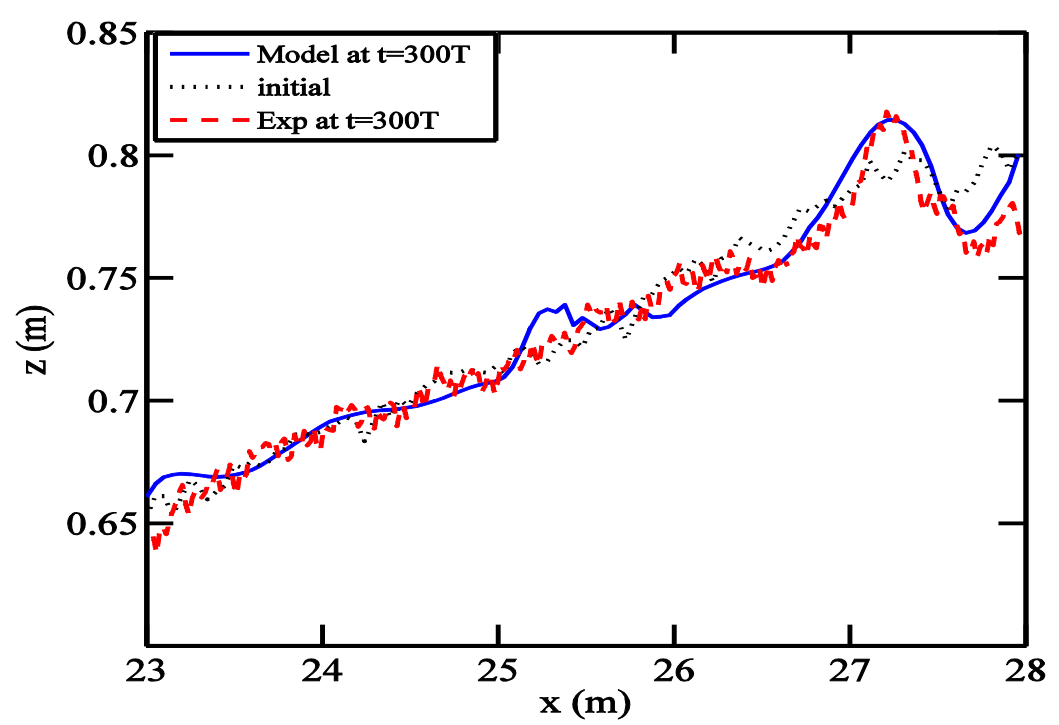

Figure 4 Calculated Beach profile at $\mathrm{t} / \mathrm{T}=50$ and measured beach profile for $\mathrm{Hs}=0.2 \mathrm{~m}, \mathrm{Tp}=1.84 \mathrm{~s}$, htoe $=0.2 \mathrm{~m}$

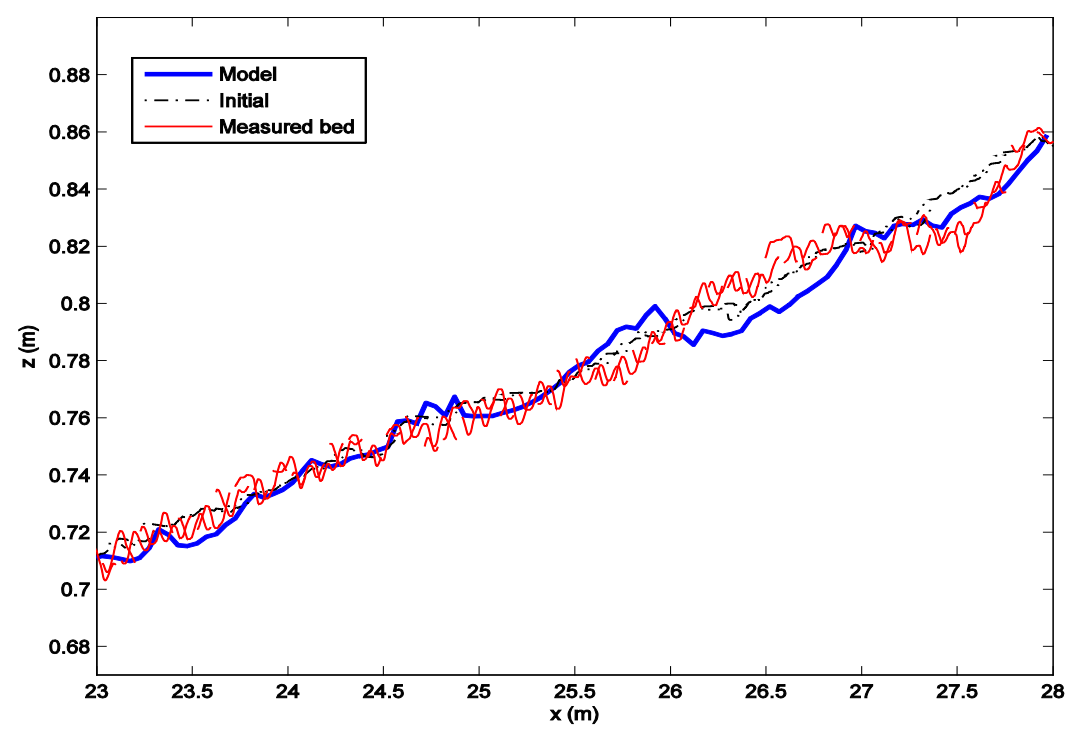

Figure 5 Calculated Beach profile at $\mathrm{t} / \mathrm{T}=50$ and measured beach profile for $\mathrm{Hs}=0.2 \mathrm{~m}, \quad \mathrm{Tp}=1.84 \mathrm{~s}$, htoe $=0.4 \mathrm{~m}$

\section{ACKNOWLEDGMENTS}

We are grateful to Drs C. Obhrai and J. Sutherland at HR Wallingford, who generously provided the laboratory measurements for the present work, along with the support of the Natural Environmental Research Council (Grant No. NE/E002129/1) and the start-up fund by University of Maine. This work benefits from discussions with Drs. A. Pedrozo-Acuna, D. Jones and Prof. D.E. Reeve. The third author acknowledges the supported by NSFC (51061130547). 


\section{REFERENCES}

Bakhtyar, R., Ghaheri, A., Yeganeh-Bakhtiary, A. and Barry, D.A., 2009. Process-based model for nearshore hydrodynamics, sediment transport and morphological evolution in the surf and swash zones. Applied Ocean Research, 31(1): 44-56.

Butt, T. and Russell, P., 2000. Hydrodynamics and cross-shore sediment transport in the swash-zone of natural beaches: A review. Journal of Coastal Research, 16(2): 255-268

Fredsøe, J. and Deigaard, R., 1992. MECHANICS OF COASTAL SEDIMENT TRANSPORT. Advanced Series on Ocean Engineering 3. World Scientific.

Fredsøe, J. and Sumer, B.M., 1997. Scour at the round head of a rubble-mound breakwater. Coastal Engineering, 29(3-4): 231-262.

Garcia, N., Lara, J.L., Losada, I.J., 2004. 2-D numerical analysis of near-field flow at low-crested permeable breakwaters. Coastal Eng. 51 (10), 991-1020.

Gislason, K., Fredsøe, J. and Sumer, B.M., 2009. Flow under standing waves: Part 2. Scour and deposition in front of breakwaters. Coastal Engineering, 56(3): 363-370.

HR Wallingford, 2006. Understanding the Lowering of Beaches in front of coastal defence structures, Phase 2: Medium scale 2D physical model tests of scour at sea walls. CBS0726/06.

Lara, J.L., Garcia, N., Losada, I.J., 2006. RANS modelling applied to random wave interaction with submerged permeable structures. Coastal Eng. 53 (5-6), 395-417.

Larson, M., Kubota, S. and Erikson, L., 2001. A Model of Sediment Transport and Profile Evolution in the Swash Zone. In: Hanson, H. and M. Larson (Editors), Coastal Dynamics '01. ASCE, Lund, Sweden pp. 908-917.

Liang, D. and Cheng, L., 2005. Numerical Model for Wave-Induced Scour below a Submarine Pipeline. Journal of Waterway, Port, Coastal, and Ocean Engineering, 131(5): 193-202.

Lin, P.Z. and Liu, P.L.F., 1998. A numerical study of breaking waves in the surf zone. Journal of Fluid Mechanics, 359: 239-264.

Madsen, O.S., 1991. Mechanics of Cohesionless Sediment Transport in Coastal Waters. In: Kraus, N.C. (Editor), Proceedings of Coastal Sediments 91'. ASCE, Seattle, Washington, pp. 15-27

Meyer-Peter, E. and Mueller, R., 1948. Formulas for bed load transport, Second Meeting of the International Association of Hydraulic Structures, Stockholm, Sweden, pp. 39-64.

Pedrozo-Acuña, A., Simmonds, D.J., Otta, A.K. and Chadwick, A.J., 2006. On the cross-shore profile change of gravel beaches. Coastal Engineering, 53(4): 335-347.

Sumer, B.M., 2007. Mathematical modelling of scour: A review. Journal of Hydraulic Research, 45(6): 723-735.

Sumer, B.M. and Fredsథe, J., 2002. The Mechanics of Scour in the Marine Environment. Advanced Series on Ocean Engineering, Vol. 17. World Scientific Publishing Co. Pte. Ltd.

Sutherland, J, C. Obhrai, R.J.S. Whitehouse and A.M.C. Pearce. (2006). Laboratory Tests of Scour at a Seawall. Proceedings, 3rd International Conference on Scour and Erosion

Troch P. and De Rouck J. 1999, An active wave generating-absorbing boundary condition for VOF type numerical model, Coastal Engineering, Vol 38(4), pp 223-247.

Tsai, C.-P., Chen, H.-B. and You, S.-S., 2009. Toe Scour of Seawall on a Steep Seabed by Breaking Waves. Journal of Waterway, Port, Coastal, and Ocean Engineering, 135(2): 61-68.

Zou, Q.-P., \& Z. Peng, 2011. Evolution of wave shape over a low-crested structure, Coastal Engineering,Vol 58, Issue 6, Pages 478-488, (doi: 10.1016/j.coastaleng. 2011.01.00)

Zou, Q.-P., Chen, Y., Cluckie, I., Hewston, R., Pan, S., Peng, Z. and Reeve, D., 2012: "Ensemble prediction of coastal flood risk arising from overtopping and scour by linking meteorological, ocean, coastal and surf zone models”, Quarterly Journal of the Royal Meteorological Society, Revised. 